\title{
PENGARUH SIKLUS BELAJAR TRI PRAMANA PADA PEMBELAJARAN IPA BERMUATAN KEARIFAN LOKAL TERHADAP KETERAMPILAN BERPIKIR KRITIS DAN KARAKTER SISWA SEKOLAH DASAR \\ Oleh
}

\author{
I Ketut Suparya \\ Sekolah Tinggi Agama Hindu Negeri Mpu Kuturan Singaraja \\ iketutsuparya@gmail.com
}

Diterima 4 Pebruari 2021, direvisi 28 Pebruari 2021, diterbitkan 1 April 2021

\begin{abstract}
Abstrak
Penelitian ini bertujuan untuk mendeskripsikan perbedaan kemampuan berpikir kritis dan karakter pada siswa kelas $\mathrm{V}$ sekolah dasar antara siswa yang mengikuti siklus belajar tri pramana dalam pembelajaran IPA bermuatan kearifan lokal dengan siswa yang mengikuti pembelajaran konvensional. Rancangan eksperimen yang digunakan dalam penelitian ini adalah pretest-posttest nonequivalent control group design dengan rancangan faktorial $2 \times 2$. Pengujian hipotesis dilakukan dengan teknik analisis multivarians (MANOVA) dengan menggunakan nilai $N$ gain. Dari hasil penelitian dapat disimpulkan sebagai berikut: (1) Terdapat perbedaan kemampuan berpikir kritis dan karakter pada siswa kelas V sekolah dasar antara siswa yang mengikuti siklus belajar tri pramana dengan siswa yang mengikuti pembelajaran konvensional dalam pembelajaran IPA bermuatan kearifan lokal. Hal ini dibuktikan berdasarkan hasil statistik dengan bantuan SPSS 17 for windows didapatkan hasil $\mathrm{F}$ untuk Wilks lambda memiliki signifikansi lebih kecil dari 0,05. (2) Terdapat perbedaan kemampuan berpikir kritis pada siswa kelas V sekolah dasar antara siswa yang mengikuti siklus belajar tri pramana dengan siswa yang mengikuti pembelajaran konvensional dalam pembelajaran IPA bermuatan kearifan lokal dengan nilai statistik statistik 4.666 dengan taraf signifikansi < 0,05. (3) Terdapat perbedaan karakter pada siswa kelas V sekolah dasar antara siswa yang mengikuti siklus belajar tri pramana dengan siswa yang mengikuti pembelajaran konvensional dalam pembelajaran IPA bermuatan kearifan lokal dengan nilai statistik $\mathrm{F}=$ 4,214 dengan taraf signifikansi $<0,05$.
\end{abstract}

Kata Kunci: tri pramana, berpikir kritis, karakter

\begin{abstract}
This study aims to describe the differences in critical thinking skills and character in grade $\mathrm{V}$ elementary school students between students who take the tri pramana learning cycle in science learning with local wisdom and students who take conventional learning. The experimental design used in this study was a pretest-posttest nonequivalent control group design with $2 \times 2$ factorial design. Hypothesis testing was performed using multivariance analysis techniques (MANOVA) using the $\mathrm{N}$ gain value. From the research results, it can be concluded as follows: (1) There are differences in critical thinking skills and character in grade V elementary school students between students who take the tri pramana learning cycle and students who take conventional learning in science learning with local wisdom. This is evidenced by the statistical results with the help of SPSS 17 for windows, the F results for Wilks lambda have a significance smaller than 0.05. (2) There is a difference in the critical
\end{abstract}


thinking ability of grade $\mathrm{V}$ elementary school students between students who take the tri pramana learning cycle and students who take conventional learning in science learning with local wisdom with a statistical value of 4.666 with a significance level of $<0.05$. (3) There is a difference in religiosity in fifth grade elementary school students between students who take the tri pramana learning cycle and students who take conventional learning in science learning with local wisdom with a statistical value of $\mathrm{F}=4.214$ with a significance level of $<0.05$.

\section{Keywords: tri pramana, critical thinking, character}

\section{PENDAHULUAN}

Mata pelajaran IPA di SD pada prinsipnya mengarahkan siswa untuk mengkontruksi pengetahuan sendiri sesuai dengan kaidah sikap ilmiah, proses ilmiah, dan produk ilmiah. Mereka harus dilatih untuk menyadari bahwa lingkungan atau alam sekitar tersebut dapat dipelajari dengan mudah melalui metode ilmiah yang di dalamnya terdapat sikap ilmiah dan berpikir kritis. Namun sayangnya, guru belum memfasilitasi siswa melakukan hal tersebut, sehingga siswa belum mampu menggali potensi dirinya untuk berpikir kritis. Kegiatan ini menyebabkan rendahnya kemampuan berpikir yang dimaksud pada diri siswa.

Beyer (Ennis, 1985) menyatakan bahwa "berpikir kritis berarti membuat penilaianpenilaian yang masuk akal. Seorang pemikir kritis hendaknya benar-benar mencerna masalah yang ada dan melihatnya dari berbagai sudut pandang". Mengacu pada pendapat di atas, guru sebagai pendidik berkewajiban untuk selalu berusaha agar dapat mengkondisikan pembelajaran sedemikian rupa sehingga mampu mengembangkan kemampuan berpikir kritis siswa. Jika pemikiran kritis siswa itu sudah dapat ditingkatkan, maka pembelajaran pun akan dapat berlangsung dengan baik. Pembelajaran yang baik akan menghasilkan kualitas luaran yang tinggi pula.

Selain kemampuan berpikir kritis, karakter siswa yang baik juga mutlak diperlukan untuk membentuk manusia yang berkualitas sesuai dengan amanat UU No 20 Tahun 2003. Kecerdasasan (kemampuan berpikir kritis) tanpa karakter yang baik akan membuat kualitas hidup menjadi rendah (Zubaedi, 2011).

Saat ini kemampuan berpikir kritis siswa sangatlah rendah. Hal tersebut dibuktikan dari hasil tes keterampilan berpikir kritis pada siswa kelas V SD gugus V kecamatan Sawan, Kabupaten Buleleng. Kegiatan tersebut dilaksanakan pada tanggal 13 Januari 2020 di SD N 2 Sangsit, SD N 5 Sangsit, SD N 6 Sangsit, dan tanggal 16 Januari 2020 di SD N 9 Sangsit, dan SD N 4 Suwug. Nilai rata-rata kemampuan berpikir kritis siswa masih berada pada interval 054. Jika dikonversikan terhadap Penilaian Acuan Patokan (PAP) skala 5, nilai tersebut berada pada predikat sangat kurang. Hal tersebut menunjukkan bahwa berpikir kritis siswa masih rendah. Untuk mengetahui penyebabnya, maka dilakukan wawancara dan observasi dengan beberapa guru IPA, siswa, dan proses pembelajaran di kelas.

Berdasarkan kegiatan tersebut, ada beberapa permasalahan yang teridentifikasi sebagai penyebab rendahnya kemampuan berpikir kritis siswa. Pertama, pembelajaran masih berpusat pada guru (teacher centered). Ke dua, guru berpandangan harus membawa siswa untuk menguasai semua materi yang ada di buku agar lulus ujian. Ke tiga, kurangnya pemahaman dan kesiapan guru melaksanakan model-model pembelajaran inovatif sehingga guru masih mengajar dengan cara-cara tradisional. Ke empat, kurangnya aktivitas fisik dan berpikir kritis siswa dalam belajar. Ke lima, saat proses pembelajaran, siswa jarang melihat fenomena nyata atau media yang berhubungan dengan materi yang dibahas.

Masalah rendahnya keterampilan berpikir kritis siswa tersebut perlu dicarikan solusi agar pembelajaran yang dilaksanakan dapat memberikan hasil yang optimal dan mampu meningkatkan keterampilan berpikir kritis. Salah satu solusinya adalah menggunakan model pembelajaran yang mampu memberikan kesempatan kepada siswa untuk membangun 
pengetahuan berdasarkan pengalaman nyata dan memotivasi mereka untuk berpikir secara kritis. Model yang dipilih dan sesuai untuk mengatasi masalah yang terjadi adalah model siklus belajar berbasis Tri Pramana. Alur siklus belajar yang dilahirkan dari konsep Tri Pramana ada enam, yaitu dua siklus dimulai dengan kegiatan Pratyaksa, dua siklus dimulai dengan kegiatan Sabda, dan dua siklus lainnya dimulai dari kegiatan Anumana. Enam siklus belajar yang dimaksud adalah (1) Model Siklus Belajar PSA, (2) Model Siklus Belajar PAS, (3) Model Siklus Belajar SAP, (4) Model Siklus Belajar SPA, (5) Model Siklus Belajar APS, dan 6) Model Siklus Belajar ASP (Subagia et al., 2008).

Berdasarkan model-model siklus belajar yang ada, model siklus belajar yang sesuai untuk anak SD adalah model PSA.(Subagia et al., 2008); (Ariestini et al., 2013); (Atmaja et al., 2013), menyatakan bahwa "pada jenjang SD, dipilih model Siklus Belajar PratyaksaSabda-Anumana (PSA) karena pembelajaran sains di SD mengutamakan pada pengkajian fenomena alam yang dapat diamati dengan pancaindera". Siklus belajar PSA menuntun siswa terlebih dahulu melakukan pengamatan langsung terhadap objek (Pratyaksa Pramana). Kemudian, siswa mencari referensi pendukung hasil pengamatan/membaca referensi (Sabda Pramana). Berikutnya, mereka menerapkan konsep pada situasi lain (Anumana Pramana). Dengan siklus PSA tersebut, siswa dapat dilatih untuk berpikir kritis sehingga mampu menerapkan konsep yang dipelajari pada situasi lain (Anumana Pramana). Pelaksanaan pembelajaran yang demikian sangat membantu anak untuk mengembangkan keterampilan berpikir kritis.

Pembelajaran IPA bisa dintegrasikan dengan muatan materi yang berbasis kearifan lokal. Pemuatan materi ini akan mampu memberikan pemahaman kepada mahasiswa terkait dengan materi IPA yang ada di dalam kehidupan sehari-hari (budaya lokal) siswa (Purna, 2010). Siklus belajar tri pramana dalam pembelajaran IPA bermuatan kearifan lokal diharapkan mampu meningkatkan karakter siswa sehingga nantinya akan membantu mereka dalam menyelesaikan banyak persoalan dalam kehidupan sehari-hari.

Mengingat masalah tersebut sangat penting, maka dilakukan penelitian dengan tujuan untuk mengetahui perbedaan yang signifikan pada keterampilan berpikir kritis dan karekater siswa dalam pembelajaran IPA antara kelompok siswa yang dibelajarkan menggunakan model siklus belajar berbasis tri pramana pada materi IPA bermuatan kearifan lokal dengan kelompok siswa yang dibelajarkan menggunakan pembelajaran konvensional pada siswa kelas V sekolah dasar Tahun Pelajaran 2019/2020. Adapun tujuan penelitian ini adalah sebagai berikut: 1) untuk mendeskripsikan perbedaan kemampuan berpikir kritis dan karakter siswa dalam pembelajaran IPA bermuatan kearifan lokal pada siswa kelas V sekolah dasar antara siswa yang mengikuti siklus belajar tri pramana dengan siswa yang mengikuti pembelajaran konvensional, 2) Untuk mendeskripsikan perbedaan kemampuan berpikir kritis dalam pembelajaran IPA bermuatan kearifan lokal pada siswa kelas IV sekolah dasar antara siswa yang mengikuti siklus belajar tri pramana dengan siswa yang mengikuti pembelajaran konvensional, 3) Untuk mendeskripsikan perbedaan karakter siswa dalam pembelajaran IPA bermuatan kearifan lokal pada siswa kelas V sekolah dasar antara siswa yang mengikuti siklus belajar tri pramana dengan siswa yang mengikuti pembelajaran konvensional.

\section{METODE}

Penelitian ini merupakan penelitian quasi eksperimen karena dalam penelitian ini, kelompok yang terlibat dalam penelitian tidak dikendalikan secara penuh (pengendalian terbatas) (Sugiyono, 2017). Dalam penelitian ini melibatkan dua kelompok kelas, yaitu 
kelompok eksperimen dan kelompok kontrol. Pengendalian terbatas yang dilakukan adalah dengan melihat kesetaraan nilai pada kelompok eksperimen dan kelompok kontrol serta tidak dilakukan pengacakan subyek dalam penelitian. Rancangan eksperimen yang digunakan dalam penelitian ini adalah pretest-posttest nonequivalent control group design dengan rancangan faktorial 2 × 2 (Dantes, 2017). Rancangan ini digunakan karena eksperimen dilakukan di dalam kelas dengan siswa yang telah ada atau peneliti tidak mungkin mengubah kelas dalam menentukan subyek penelitian. Untuk lebih jelasnya, berikut disajikan tabel rancangan penelitian.

\section{Tabel 01 Rancangan Eksperimen}

\begin{tabular}{|l|c|c|c|}
\hline Kelompok & $\begin{array}{c}\text { Pre } \\
\text { Tes }\end{array}$ & Treatment & $\begin{array}{c}\text { Post } \\
\text { Test }\end{array}$ \\
\hline Eksperimen & O1 & $\mathrm{X}$ & O3 \\
\hline Kontrol & O2 & - & O4 \\
\hline
\end{tabular}

Keterangan
$\mathrm{X} \quad$ : Siklus belajar tri pramana
O1 : pre tes pada kelompok eksperimen
$\mathrm{O} 2$ : pre tes pada kelompok kontrol
O3 : Post Test pada kelompok eksperimen

Dalam penelitian Penelitian ini melibatkan dua variabel terikat yaitu: pemahaman sikap sosial dan hasil belajar. Oleh karena itu analisis data penelitian ini mengikuti rancangan seperti Tabel 02.

Tabel 02. Matriks Rancangan Analisis

Keterangan:

\begin{tabular}{|l|l|l|l|}
\hline \multicolumn{2}{|c|}{$\mathrm{A}_{1}$} & \multicolumn{2}{|c|}{$\mathrm{A}_{2}$} \\
\hline $\mathrm{Y}_{1}$ & $\mathrm{Y}_{2}$ & $\mathrm{Y}_{1}$ & $\mathrm{Y}_{2}$ \\
\hline
\end{tabular}

$\mathrm{A}_{1}$ : siklus belajar tri pramana

$\mathrm{A}_{2}$ : pembelajaran konvensional

$\mathrm{Y}_{1}$ : keterampilan berpikir kritis

$\mathrm{Y}_{2}$ : karakter siswa

Pengujian hipotesis yang digunakan untuk menguji pengaruh siklus belajar tri pramana menggunakan nilai $N$ gain (Dantes, 2017). Gain ternormalisasi (N-gain) untuk setiap siswa dapat dihitung dengan menggunakan rumus berikut ini.

$$
N_{-} \text {Gain }=\left[\frac{(\text { Spost }- \text { Spre }}{\text { Smax }- \text { Spre }}\right]
$$

\section{Keterangan :}

$\mathrm{N}$-Gain = gain ternormalisasi

$\mathrm{S}_{\text {post }}=$ skor posttest

$\mathrm{S}_{\mathrm{pre}}=$ skor pretest

$S_{\max }=$ skor maksimum

Menurut (Dantes, 2017), hasil perhitungan dari N-gain juga dapat dikategorikan sebagai berikut. 


\section{Tabel 03. Klasifikasi Interpretasi Nilai Gain Ternormalisasi}

\begin{tabular}{|c|c|}
\hline Nilai N-gain & Interpretasi \\
\hline $\mathrm{g} \geq 70 \%$ & Tinggi \\
\hline & \\
\hline $30 \% \leq \mathrm{g}<70 \%$ & Sedang \\
\hline $\mathrm{g}<30 \%$ & Rendah \\
\hline
\end{tabular}

(sumber:Dantes,2017)

Nilai gain ternormalisasi yang diperoleh digunakan untuk melihat adanya peningkatan hasil belajar siswa sebelum dan setelah diberi perlakuan dengan pembelajaran menggunakan bahan ajar yang dikembangkan. Nilai gains ternormalisasi selanjutnya dianilis

Pengujian hipotesis dilakukan dengan teknik analisis multivarians (MANOVA). Hal ini mengingat variasi total sebuah subyek dalam suatu eksperimen dapat dianalisis menjadi dua sumber varians yaitu varians antar kelompok. Sedangkan untuk menguji berpedaan dua mean atau lebih digunakan ANAVA satu jalur. Uji multivariat atau pengujian antar subyek yang dilakukan terhadap angka - angka signifikansi dari nilai F statistik Pillas's Trace, Wilk's Lambda, Hotelling Trace, Roy's Largest Root (Santoso:2002). Angka signifikan lebih kecil dari 0,005 berati $\mathrm{H}_{0}$ ditolak, yang artinya terdapat perbedaan variabel dependen (Candiasa, 2007).

\section{HASIL PENELITIAN DAN PEMBAHASAN}

\section{Hasil Penelitian}

Variabel dalam penelitian ini adalah keterampilan berpikir kritis dan karakter siswa. Keterampilan berpikir kritis diukur dengan tes dan data karakter siswa diukur dengan kuisioner. Tendensi sentral dari data yang didapatkan dapat dilihat pada Tabel 04.

Tabel 04. Rekapitulasi Hasil Perhitungan

Skor Kemampuan Berpikir kritis dan Karakter Siswa

\begin{tabular}{|l|c|c|c|c|c|c|c|c|}
\hline $\begin{array}{c}\text { Data } \\
\text { Statistik }\end{array}$ & $\mathbf{x 1 . 0 1}$ & $\begin{array}{c}\text { Y1.0 } \\
\mathbf{1}\end{array}$ & $\mathbf{x 1 . 0 2}$ & $\mathbf{\text { y1.02 }}$ & $\mathbf{x 2 . 0 1}$ & $\mathbf{\text { Y1201 }}$ & $\mathbf{\text { X2.02 }}$ & Y2.02 \\
\hline Mean & 66,63 & $\begin{array}{c}66, \\
50\end{array}$ & 79,03 & 78,38 & 69,81 & 70,86 & 83,22 & 83,19 \\
\hline Median & 67,50 & $\begin{array}{c}67, \\
50\end{array}$ & 78 & 78 & 70 & 72 & 82 & 82 \\
\hline $\begin{array}{l}\text { Standar } \\
\text { deviasi }\end{array}$ & 5,51 & $\begin{array}{c}5,3 \\
7\end{array}$ & 4,45 & 3,99 & 4,53 & 4,54 & 4,03 & 3,73 \\
\hline Varians & 31,11 & $\begin{array}{c}29, \\
59\end{array}$ & 20,28 & 16,34 & 21,05 & 21,18 & 16,73 & 14,32 \\
\hline Rentangan & 23 & 23 & 16 & 20 & 18 & 20 & 17 & 12 \\
\hline $\begin{array}{l}\text { Skor } \\
\text { maksimum }\end{array}$ & 78 & 78 & 86 & 92 & 78 & 80 & 92 & 90 \\
\hline
\end{tabular}




\begin{tabular}{|l|c|c|c|c|c|c|c|c|}
\hline $\begin{array}{l}\text { Skor } \\
\text { minimum }\end{array}$ & 55 & 55 & 70 & 72 & 60 & 60 & 75 & 78 \\
\hline
\end{tabular}

Keterangan:

X1.O1 : $\quad$ data pre test keterampilan berpikir kritis siswa yang mengikuti siklus konvensional

Y1.O1 : data pre test karakter siswa yang mengikuti siklus konvensional

X1.O2 : data post test keterampilan berpikir kritis siswa yang mengikuti siklus konvensional

Y1.O2: data post test karakter siswa yang mengikuti siklus konvensional

X2.O1 : data pre test keterampilan berpikir kritis siswa yang mengikuti siklus tri pramana

Y2.O1 : $\quad$ data pre test karakter siswa yang mengikuti siklus tri pramana

X2.O2 : data post test keterampilan berpikir kritis siswa yang mengikuti siklus tri pramana

Uji hipotesis dilakukan dengan formula one-way MANOVA menggunakan bantuan SPSS 17 for windows. Sebelum dilakukan uji hipotesis terlebih dahulu dilakukan uji prasyarat. Uji prasyarat tersebut adalah uji normalitas, uji homogenitas varians, uji homogenitas, homogenitas matriks varian, uji multikolinieritas. Uji prasyarat analisis mutlak dilakukan sebelum uji manova, uji manova bisa dilakukan jika data terdistribusi normal, homogen, homogenitas matriks varian tidak siginifikan, dan tidak terjadi multikolinieritas diantara variabel terikat. Hasil analasis uji prasyarat dapat dilihat pada Tabel 05, Tabel 06, Tabel 07, Tabel 08.

Tabel 05. Uji Normalitas Sebaran Data Menurut Model Pembelajaran

\begin{tabular}{|c|c|c|c|c|l|}
\hline Variabel & Model Pembelajaran & \multicolumn{3}{|c|}{ Kolmogorov-Smirnov } & \multicolumn{1}{|c|}{ Keputusan } \\
\cline { 3 - 6 } dependen & Ktatistik & df & Sig & Normal \\
\hline $\begin{array}{c}\text { Kemampuan } \\
\text { berpikir kritis }\end{array}$ & Konvensional & 0,129 & 40 & 0,069 & Normal \\
\hline Karakter Siswa & Konvensional & 0,115 & 40 & 0,182 & Normal \\
\hline $\begin{array}{c}\text { Kemampuan } \\
\text { berpikir kritis }\end{array}$ & $\begin{array}{c}\text { Siklus Belajar Tri } \\
\text { pramana }\end{array}$ & 0,191 & 37 & 0,06 & Normal \\
\hline Karakter Siswa & $\begin{array}{c}\text { Siklus Belajar Tri } \\
\text { pramana }\end{array}$ & 0,180 & 37 & 0,061 & Normal \\
\hline
\end{tabular}

(sumber: Lampiran uji analisis dengan SPSS)

Tabel 06 Hasil Uji Homogenitas Varians Antar Kelompok

\begin{tabular}{|c|c|c|c|c|c|}
\hline \multicolumn{5}{|c|}{$\begin{array}{c}\text { Levene's Test of Equality } \\
\text { of Error Variances }{ }^{\text {a }}\end{array}$} & \multirow{2}{*}{$\begin{array}{c}\text { Keter } \\
\text { anga } \\
\mathrm{n}\end{array}$} \\
\hline & $\mathrm{F}$ & df1 & $\mathrm{df} 2$ & Sig. & \\
\hline $\begin{array}{c}\text { K. } \\
\text { Kritis }\end{array}$ & $\begin{array}{c}4,24 \\
3\end{array}$ & 1 & 77 & $\begin{array}{c}0,06 \\
2\end{array}$ & \multirow{2}{*}{$\begin{array}{l}\text { Hom } \\
\text { ogen }\end{array}$} \\
\hline \begin{tabular}{|c|} 
karakte \\
$\mathrm{r}$ \\
\end{tabular} & $\begin{array}{c}0,75 \\
3\end{array}$ & 1 & 77 & $\begin{array}{c}0,38 \\
8\end{array}$ & \\
\hline
\end{tabular}

(sumber: Lampiran uji analisis dengan SPSS) 
Tabel 07. Uji Tek Box's M

\begin{tabular}{|c|c|c|}
\hline Box's & 16.892 & Keterangan \\
\hline $\mathrm{F}$ & 5.468 & \multirow{4}{*}{$\begin{array}{c}\text { Hasil analisis } \\
\text { tidak signifikan } \\
\text { Uji Manova bisa } \\
\text { dilanjutkan }\end{array}$} \\
\hline df1 & 3 & \\
\hline df2 & $1.267 \mathrm{E} 6$ & \\
\hline Sig. & .06 & \\
\hline
\end{tabular}

(sumber: Lampiran uji analisis dengan SPSS)

Tabel 08. Hasil Uji Multikolinieritas

\begin{tabular}{|c|c|c|c|c|}
\hline \multirow{2}{*}{ Model } & & \multicolumn{2}{|c|}{ Collinearity Statistics } & \multirow{2}{*}{ Keterangan } \\
\cline { 3 - 4 } & & $\begin{array}{c}\text { Toler } \\
\text { ance }\end{array}$ & VIF & \\
\hline Siklus Tri pramana & $\mathrm{y}_{1} \mathrm{y}_{2}$ & 0,945 & 1,059 & \multirow{2}{*}{$\begin{array}{c}\text { Tidak terjadi } \\
\text { multikolinieritas }\end{array}$} \\
\hline Konvensional & $\mathrm{y}_{1} \mathrm{y}_{2}$ & 0,945 & 1,059 & . \\
\hline
\end{tabular}

(sumber: Lampiran uji analisis dengan SPSS)

\section{Pengujian Hipotesis}

\section{a. Uji Hipotesis Pertama}

$\mathrm{H}_{0}$ : tidak terdapat perbedaan kemampuan berpikir kritis dan karakter pada siswa kelas V sekolah dasar antara siswa yang mengikuti siklus belajar tri pramana dengan siswa yang mengikuti pembelajaran konvensional dalam pembelajaran IPA bermuatan kearifan lokal.

$\mathrm{H}_{\mathrm{a}}$ : terdapat perbedaan kemampuan berpikir kritis dan karakter pada siswa kelas V sekolah dasar antara siswa yang mengikuti siklus belajar tri pramana dengan siswa yang mengikuti pembelajaran konvensional dalam pembelajaran IPA bermuatan kearifan lokal.

Kriteria pengujian: jika harga $F$-Wilk' Lamda menghasilkan angka signifikansi kurang dari 0,05 maka hipotesis nol ditolak dan dalam hal lain hipotesis diterima (Santoso, 2002:219). Perbedaan keterampilan berpikir kritis dan karakter siswa pada siswa yang dibelajarkan dengan model tri pramana dibandingkan dengan siswa yang mengikuti pembelajaran konvensional dapat diketahui dari perhitungan dengan menggunakan one-way MANOVA, adapun perhitungannya dilakukan dengan menggunakan bantuan program SPSS 17 for windows. Data analisis MANOVA dapat dilihat pada Tabel 09. 
ADI WIDYA: Jurnal Pendidikan Dasar FAKULTAS DHARMA ACARYA UNIVERSITAS HINDU NEGERI

I GUSTI BAGUS SUGRIWADENPASAR
Volume. 6, Nomor 1 April 2021

ISSN: 2685-8312 (online)

ISSN: 2527-5445 (cetak

http://ejournal.ihdn.ac.id/index.php/AW

Tabel 09. Rekapitulasi Hasil Perhitungan Keterampilan Berpikir Kritis dan Karakter Siswa dengan One-Way MANOVA

\begin{tabular}{|l|l|l|l|r|r|r|}
\hline \multicolumn{2}{|c|}{ Effect } & Value & F & Hypothesis df & Error df & Sig. \\
\hline \multirow{4}{*}{ Intercept } & Pillai's Trace & .896 & $3.176 \mathrm{E} 2^{\mathrm{a}}$ & 2.000 & 74.000 & .000 \\
\cline { 2 - 7 } & Wilks' Lambda & .104 & $3.176 \mathrm{E} 2^{\mathrm{a}}$ & 2.000 & 74.000 & .000 \\
\cline { 2 - 7 } & Hotelling's Trace & 8.582 & $3.176 \mathrm{E} 2^{\mathrm{a}}$ & 2.000 & 74.000 & .000 \\
\cline { 2 - 7 } & Roy's Largest Root & 8.582 & $3.176 \mathrm{E} 2^{\mathrm{a}}$ & 2.000 & 74.000 & .000 \\
\hline \multirow{5}{*}{ M.Belajar } & Pillai's Trace & .072 & $2.869^{\mathrm{a}}$ & 2.000 & 74.000 & .063 \\
\cline { 2 - 7 } & Wilks' Lambda & .928 & $2.869^{\mathrm{a}}$ & 2.000 & 74.000 & .063 \\
\cline { 2 - 7 } & Hotelling's Trace & .078 & $2.869^{\mathrm{a}}$ & 2.000 & 74.000 & .063 \\
\cline { 2 - 7 } & Roy's Largest Root & .078 & $2.869^{\mathrm{a}}$ & 2.000 & 74.000 & .063 \\
\hline
\end{tabular}

Hasil analisis tersebut menunjukkan bahwa harga F untuk Pillai's Trace, Hotelling's Trace, Roy's Largest Root, Wilks' Lambda memiliki signifikansi lebih kecil dari 0,05. Artinya harga F untuk Wilks' Lambda signifikan. Dari hasil analisis menunjukkan terdapat perbedaan kemampuan berpikir kritis dan karakter pada siswa kelas V sekolah dasar antara siswa yang mengikuti siklus belajar tri pramana dengan siswa yang mengikuti pembelajaran konvensional dalam pembelajaran IPA bermuatan kearifan lokal.

\section{b. Hipotesis Kedua}

$\mathrm{H}_{0}$ : tidak terdapat perbedaan kemampuan berpikir kritis pada siswa kelas V sekolah dasar antara siswa yang mengikuti siklus belajar tri pramana dengan siswa yang mengikuti pembelajaran konvensional dalam pembelajaran IPA bermuatan kearifan local

$\mathrm{H}_{\mathrm{a}}$ : terdapat perbedaan kemampuan berpikir kritis pada siswa kelas V sekolah dasar antara siswa yang mengikuti siklus belajar tri pramana dengan siswa yang mengikuti pembelajaran konvensional dalam pembelajaran IPA bermuatan kearifan lokal

Pengujian hipotesis kedua menggunakan mengunakan SPSS 17 for windows. Analisis dilakukan dengan melihat nilai $\mathrm{F}$ varians dari Tabel Tests of Between-Subjects Effects. Kriteria pengujian adalah tolak $\mathrm{H}_{0}$ jika angka signifikansi < 0,05 , data analisis dapat dilihat pada Tabel 10 .

Tabel 10. Tests of Between-Subjects Effects

\begin{tabular}{|l|l|l|r|r|r|r|}
\hline Source & $\begin{array}{l}\text { Dependent } \\
\text { Variable }\end{array}$ & $\begin{array}{l}\text { Type III } \\
\text { Sum of } \\
\text { Squares }\end{array}$ & df & $\begin{array}{c}\text { Mean } \\
\text { Square }\end{array}$ & \multicolumn{1}{|c|}{ F } & \multirow{2}{*}{ Sig. } \\
\hline Corrected Model & B.Kritis & $1042.176^{\mathrm{a}}$ & 1 & 1042.176 & 4.666 & .034 \\
\cline { 2 - 9 } & Karakter & $1055.992^{\mathrm{b}}$ & 1 & 1055.992 & 4.214 & .044 \\
\hline
\end{tabular}

Berdasarkan hasil analisis pengaruh siklus pembelajaran terhadap keterampilan berpikir kritis diperoleh nilai statistik $\mathrm{F}=4.666$ dengan taraf signifikansi $<0,05$. Berdasarkan hasil analisis menunjukkan terdapat perbedaan kemampuan berpikir kritis pada siswa kelas $\mathrm{V}$ sekolah dasar antara siswa yang mengikuti siklus belajar tri pramana dengan siswa yang mengikuti pembelajaran konvensional dalam pembelajaran IPA bermuatan kearifan lokal 


\section{c. Uji Hipotesis Ketiga}

$\mathrm{H}_{0}$ : tidak terdapat perbedaan karakter pada siswa kelas $\mathrm{V}$ sekolah dasar antara siswa yang mengikuti siklus belajar tri pramana dengan siswa yang mengikuti pembelajaran konvensional dalam pembelajaran IPA bermuatan kearifan lokal.

$\mathrm{H}_{\mathrm{a}}$ : terdapat terdapat perbedaan karakter pada siswa kelas V sekolah dasar antara siswa yang mengikuti siklus belajar tri pramana dengan siswa yang mengikuti pembelajaran konvensional dalam pembelajaran IPA bermuatan kearifan lokal.

Pengujian hipotesis kedua menggunakan mengunakan SPSS 17 for windows. Analisis dilakukan dengan melihat nilai $\mathrm{F}$ varians dari Tabel Tests of Between-Subjects Effects. Kriteria pengujian adalah tolak $\mathrm{H}_{0}$ jika angka signifikansi $<0,05$., data analisis dapat dilihat pada Tabel 11.

Tabel 11. Tests of Between-Subjects Effects

\begin{tabular}{|c|c|c|c|c|c|c|}
\hline Source & $\begin{array}{l}\text { Dependent } \\
\text { Variable }\end{array}$ & $\begin{array}{l}\text { Type III } \\
\text { Sum of } \\
\text { Squares }\end{array}$ & df & $\begin{array}{c}\text { Mean } \\
\text { Square }\end{array}$ & $\mathrm{F}$ & Sig. \\
\hline \multirow[t]{2}{*}{ Corrected Model } & B.Kritis & $1042.176^{a}$ & 1 & 1042.176 & 4.666 & .0 \\
\hline & Karakter & $1055.992^{\mathrm{b}}$ & 1 & 1055.992 & 4.214 & .0 \\
\hline
\end{tabular}

Berdasarkan hasil analisis pengaruh siklus pembelajaran terhadap karakter siswa diperoleh nilai statistik $F=4.214$ dengan taraf signifikansi $<0,05$. Dengan demikian terdapat perbedaan karakter pada siswa kelas $\mathrm{V}$ sekolah dasar antara siswa yang mengikuti siklus belajar tri pramana dengan siswa yang mengikuti pembelajaran konvensional dalam pembelajaran IPA bermuatan kearifan lokal.

\section{PEMBAHASAN}

\section{a. Pengaruh Siklus Pembelajaran terhadap Keterampilan Berpikir Kritis dan Karakter Siswa}

Hasil tes pada kelompok kontrol, didapatkan bahwa skor rata-rata pre tes keterampilan berpikir kritis diperoleh sebesar 66,63 dengan simpangan baku sebesar 5,51 dan rata-rata skor pre test karakter siswa diperoleh sebesar 66,50 dengan simpangan baku sebesar 5,37. Data post test rerata keterampilan berpikir kritis pada kelompok kontrol adalah 73,03 dengan simpangan baku 4,45. Data post test rerata karakter siswa pada kelompok control 78,38 dengan simpangan baku 3,99. Sedangkan data yang diperoleh pada kelompok eksperimen, rata-rata skor pre test untuk keterampilan berpikir kritis diperoleh sebesar 69,81 dengan simpangan baku sebesar 4,53 dan rata-rata karakter siswa diperoleh sebesar 70,86 dengan simpangan baku sebesar 4,54. Data pre test rerata karakter siswa pada kelompok control 78,38 dengan simpangan baku 3,99. Data yang diperoleh pada kelompok eksperimen, rata-rata skor post test untuk keterampilan berpikir kritis diperoleh sebesar 83,22 dengan simpangan baku sebesar 4,03 dan rata-rata karakter siswa diperoleh sebesar 83,19 dengan simpangan baku sebesar 3,37.

Secara umum akibat diberi perlakuan model pembelajaran yang berbeda menunjukkan hasil yang berbeda. Setelah dilakukan ekperimen, secara keseluruhan ada peningkatan skor rata-rata kemampuan berpikir kritis dan karakter siswa. Para siswa yang diberi perlakuan dengan penerapan siklus tri pramana menunjukkan pencapaian skor yang lebih tinggi dibandingkan dengan siswa yang hanya difasilitasi dengan pembelajaran konvensional. 
ADI WIDYA: Jurnal Pendidikan Dasar FAKULTAS DHARMA ACARYA UNIVERSITAS HINDU NEGERI
Volume. 6, Nomor 1 April 2021

ISSN: 2685-8312 (online)

ISSN: 2527-5445 (cetak

http://ejournal.ihdn.ac.id/index.php/AW

b. Siklus Pembelajaran Tri pramana versus Pembelajaran Konvensional dalam Pencapaian Keterampilan Berpikir Kritis

Memperhatikan skor rerata keterampilan berpikir kritis dari kelompok eksperimen maupun kelompok kontrol, skor rerata kelompok siswa yang mengikuti pembelajaran dengan siklus pembelajaran Tri pramana lebih tinggi dibandingkan dengan siswa yang mengikuti pembelajaran konvensional. Hal ini menunjukkan secara deskriptif strategi pembelajaran MTKP lebih ungul dibandingkan dengan pembelajaran konvensional.

Hasil yang diperoleh ini sejalan dengan beberapa penelitian yang telah dilakukan dalam bidang sains dan matematika. Suparya (2020) menyebutkan bahwa strategi kooperatif memiliki pengaruh yang kuat untuk mengukur perolehan belajar tambahan, termasuk keterampilan berpikir kritis dan perkembangan kognitif. Strategi MTPK memiliki landasan konseptual dan ciri yang berbeda dengan strategi kooperatif yang lain. Dalam penelitian ini perbedaan semakin jelas kelihatan dari sintaknya, yang selanjutnya diuraikan lebih operasional dalam rencana pelaksanaan pembelajaran (RPP). Selama proses kegiatan tersebut berlangsung, pada setiap anak akan terjadi proses pembelajaran keterampilan sosial yang meliputi komunikasi, membangun kepercayaan individu, penanganan masalah, serta pengambilan keputusan.

Dalam penelitian ini, kemampuan berpikir kritis akan terekpresi lewat skor yang dicapai siswa dari hasil tes tulis dengan menggunakan model open-ended assessment, meliputi aspek-aspek yang terekspresi lewat keterampilan: (1) berfokus pada pertanyaan (merumuskan masalah), (2) menganalisis argumen, 3) melakukan deduksi, (4) melakukan induksi, (5) membuat penilaian, dan (6) menentukan tindakan (diadaptasi dari Ennis, 1985; Marzamo, 1998). Berpikir kritis merupakan proses terorganisasi yang melibatkan proses mental yang menyangkut di dalamnya pemecahan masalah, pengambilan keputusan, menganalisis, dan aktivitas inkuiri ilmiah (Bachman, 2015; Suparya, 2020).

Dalam penelitian ini pengukuran dimensi berpikir kritis masih terbatas. Seperti misalnya pengukuran kemampuan siswa untuk merumuskan masalah, peneliti hanya menilai seberapa banyak siswa dapat mengajukan pertanyaan terkait dengan permasalahan yang diberikan. Peneliti tidak menganalisis lebih jauh tentang kualitas pertanyaan yang diajukan, ini dikarenakan keterbatasan kemampuan kognitif siswa. Dari temuan yang didapat terlihat kemampuan berpikir kritis siswa berada pada kategori baik, namun kalau dilihat secara nominal skor rerata yang diperoleh siswa masih sangat rendah, jauh dibawah skor ketuntasan belajar. Ada dua faktor yang menjadi penyebab masih rendahnya kemampuan berpikir kritis.

Pertama, siswa masih belum terbiasa dengan model soal yang diberikan. Ini dikarenakan siswa biasanya hanya diberi soal pilihan ganda yang sifatnya mengingat semata, sehingga kesempatan anak untuk menggunakan kemampuan yang dimiliki untuk berpikir divergen tidak terlatihkan. Ini yang menyebabkan dari temuan peneliti banyak siswa kelihatan enggan mengerjakan soal ketika soal tersebut adalah soal essay.

Kedua, siswa masih belum bisa berpikir secara sistematis. Ini terlihat dari jawabanjawaban yang disajikan tidak runut sesuai dengan pertanyaan yang diminta. Ini disebabkan karena siswa baru pertama kali mendapatkan model tes yang mengukur kemampuan berpikir kritis, selama ini soal hanya mengacu pada ketuntasan belajar tanpa mempertimbangkan untuk melatihkan kemampuan berpikir tingkat tinggi dari siswa.

\section{c. Siklus Pembelajaran Tri pramana versus Pembelajaran Konvensional dalam Pencapaian Karakter Siswa}


Memperhatikan skor rerata karakter siswa dari kelompok eksperimen maupun kelompok kontrol, skor rerata kelompok siswa yang mengikuti pembelajaran dengan tri pramana lebih tinggi dibandingkan dengan siswa yang mengikuti pembelajaran konvensional. Kegiatan pembelajaran yang ditekankan dalam tri pramana adalah prosesnya, pembelajaran yang berpusat pada siswa, yang mendorong siswa untuk lebih aktif dan menarik. Memanfaatkan pengalaman siswa sebagai acuan untuk memperoleh pengetahuan lebih dan menjadikan pembelajaran lebih bermakna. Dalam penelitian ini karakter yang diutamakan adalah karakter jujur, disiplin, kerja keras dan mandiri. Keempat nilai karakter ini sangat terkait dengan sikap ilmiah yang dibelajarkan pada pembelajaran IPA di Kelas V sekolah dasar khususnya materi ekosistem.

Nilai karakter jujur dapat dilihat dari kejujuran anak dalam menjawab tugas-tugas yang diberikan oleh guru. Meskipun pembelajaran dilaksanakan secara online tetapi siswa tetap dilatihkan kejujuran nya dalam menjawab tugas sehingga tidak orang tuanya yang menjawab tugas tersebut. Karakter disiplin anak tercermin dari kesungguhan anak dalam mengerjakan dan mengumpulkan tugas mereka sesuai dengan deadline waktu yang telah ditentukan oleh guru. Kerja keras tercermin dari kesungguhan anak dalam mempelajari materi yang diberikan oleh guru meskipun mereka belajar tidak dengan tatap muka. Mandiri tercermin dari keseriusan anak dalam mengerjakan tugas meskipun guru hanya mendampingi lewat online ternyata siswa mampu mengerjakan tugas dengan baik.

Peningkatan karakter anak melalui penerapan siklus belajar tri pramana tidak terlepas dari setting pembelajaran yang memberikan kesempatan bagi anak untuk melatihkan sikap ilmiah siswa yang berkaitan dengan karakter siswa. Peran orang tua sangat penting dalam peningkatan karakter anak selama pembelajaran online learning. Pendidikan karakter dalam keluarga yang diajarkan orangtua kepada anak dilakukan melalui: 1) diajarkan melalui pembiasaan dalam kehidupan sehari-hari, orangtua berperan sebagai role model, dilakukan dalam setting informal; 2) bersumber utama dari keluarga, lingkungan, dan sekolah; 3) lebih mudah ditularkan melalui pembiasaan daripada diajarkan dalam bentuk pelajaran; orangtua mengajarkan karakter kepada anak didasari budaya dan adat-istiadat yang melekat di sekitarnya.

\section{SIMPULAN}

Berdasarkan deskripisi umum hasil penelitian, pengujian hipotesis dan pembahasan, dapat disampaikan beberapa kesimpulan sebagai berikut: 1) terdapat perbedaan kemampuan berpikir kritis dan karakter pada siswa kelas $\mathrm{V}$ sekolah dasar antara siswa yang mengikuti siklus belajar Tri Pramana dengan siswa yang mengikuti pembelajaran konvensional dalam pembelajaran IPA bermuatan kearifan lokal. Hal ini dibuktikan berdasarkan hasil statistik dengan bantuan SPSS 17 for windows didapatkan hasil F untuk Wilks lambda memiliki signifikansi lebih kecil dari 0,05. (2) Berdasarkan hasil analisis pengaruh metode pembelajaran terhadap kemampuan berpikir kritis diperoleh nilai statistik statistik 4.666 dengan taraf signifikansi $<0,05$. Dengan demikian terdapat perbedaan kemampuan berpikir kritis pada siswa kelas V sekolah dasar antara siswa yang mengikuti siklus belajar Tri Pramana dengan siswa yang mengikuti pembelajaran konvensional dalam pembelajaran IPA bermuatan kearifan lokal. (3) Berdasarkan hasil analisis pengaruh model pembelajaran terhadap karakter siswa diperoleh nilai statistik $F=4,214$ dengan taraf signifikansi $<0,05$. Dengan demikian terdapat perbedaan karakter pada siswa kelas $\mathrm{V}$ sekolah dasar antara siswa yang mengikuti siklus belajar Tri Pramana dengan siswa yang mengikuti pembelajaran konvensional dalam pembelajaran IPA bermuatan kearifan lokal. 


\section{DAFTAR PUSTAKA}

Ariestini, I Made, Arcana, I Nym, Dibia, I.K. (2013). PENGARUH MODEL SIKLUS BELAJAR BERDASARKAN KONSEP TRI PRAMANA. E-Jurnal Pendidikan Ganesha.

Atmaja. S.N.P., Agung, A.A.G., Agustiana, I.G.A.T., Pgsd, J., \& Tp, J. (2013). PENGARUH MODEL PEMBELAJARAN INKUIRI TERBIMBING BERBASIS KONSEP TRI PRAMAN TERHADAP HASIL BELAJAR IPA SISWA KELAS V DI SDN SANGSIT. 1.

Bachman, E. (2015). Metode Belajar Berpikir Kritis dan Inovatif. Jakarta. Prestasi Pustaka.

Candiasa, I.M. (2007). Statistik Multivariat Disertai Petunjuk Analisis dengan SPSS. Program Pasca Sarjana Universitas Pendidikan Ganesha.

Dantes, N. (2017. Desain Eksperimen dan Analisis Datatle. PT. RajaGrafindo Persada.

Ennis, R.H. (1985). Goal for A Critical Thinking Curriculum in A.L Costa (ED. In Developing Minds : A Resource Bookfor Teaching Thinking. Alexandria: ASCD, 54-57.

Marzano. Et.al. (1988). Dimensions of Thinking : A Frame work for Curriculum and Instructions. Virginia: associations for Supervision and Curriculum Development.

Purna, I.M. 92010). Apresiasi Kearifan Lokal Dalam Pembangunan Budaya. BSNT Bali, NTB, NTT

Suparya, I.K. (2020) PENGARUH METODE BELAJAR TRI KAYA PARISUDHA PADA PEMBELAJARAN IPA BERMUATAN KEARIFAN LOKAL.

Sugiyono. (2017). Metode Penelitian Pendidikan (Pendekatan Kuantitatif, Kualitatif dan $R$ \& D. Alfabeta.

TERHADAP KETERAMPILAM BERPIKIR KRITIS DAN RELIGIUSITAS SISWA SEKOLAH DASAR. ADI WIDYA: Jurnal Pendidikan Dasar, Vol 5 No 1, 17-28. https://doi.org/10.25078/aw.v5i1.1252

Subagia, I.W., Gusti, I., \& Wiratma, L. (2008). EVALUASI PENERAPAN MODEL SIKLUS BELAJAR DI SMA. 41(2), 272-288.

Zubaedi. (2011). Desain Pendidikan Karakter. Jakarta: Kencana Prenada Media Group. 